\title{
CHARM OF PAST MEMORIES - VILLA ARCHITECTURE IN JAŚKOWA DOLINA IN GDAŃSK-WRZESZCZ
}

\section{DAWNYCH WSPOMNIEŃ CZAR - ARCHITEKTURA WILLOWA JAŚKOWEJ DOLINY W GDAŃSKU-WRZESZCZU}

\section{Jan Kurek}

Dr hab. inż. arch

Author's Orcid number: 0000-0002-0853-5312

Krakowska Akademia im. A.F. Modrzewskiego

Wydział Architektury i Sztuk Pięknych

\begin{abstract}
Wrzeszcz is one of the oldest suburban districts, incorporated into Gdańsk in 1814. In the nineteenth century, the district gained railway and tram connections and it developed dynamically. Rural buildings quickly gave way to manor houses, new villa districts were created. In the picturesque surroundings of forested hills, new eclectic villas were built along Jaśkowa Dolina Street. Most of them survived World War II and still enchants us with their beauty.
\end{abstract}

Key words: Gdańsk-Wrzeszcz, Jaśkowa Dolina, villa buildings.

\section{STRESZCZENIE}

Wrzeszcz jest jedną z najstarszych dzielnic podmiejskich, którą w 1814 r. przyłączono do Gdańska. W wieku XIX dzielnica uzyskała połączenia kolejowe i tramwajowe i dynamicznie się rozwijała. Zabudowa wiejska szybko ustępowała zabudowie dworkowej, powstawały nowe dzielnice willowe. W malowniczym otoczeniu zalesionych wzgórz powstawały nowe eklektyczne wille wzdłuż ulicy Jaśkowa Dolina. Większość z nich przetrwała II wojnę światową i do dziś oczarowuje nas swoim pięknem.

Słowa kluczowe: Gdańsk-Wrzeszcz, Jaśkowa Dolina, zabudowa willowa. 


\begin{abstract}
There was once a city - in addition to the suburbs of Ohra, Schidlitz, Oliva, Emmaus, Praust, Sankt Albrecht, Schellmühl, and the seaport suburb of Neufahrwasser, it had a suburb named Langfuhr. Langfuhr was so big and so little that whatever happens could happen in this world, also happened or could have happened in Langfuhr.
\end{abstract}

/Günter Grass, Dog Years/

\title{
1. INTRODUCTION
}

Wrzeszcz (Langführ in German) is one of Gdańsk's oldest districts. The first mention about it is dated to 1263 and presents it as a small settlement near Gdańsk. The life of its inhabitants at the time revolved around the River Strzyża (Strieß) and its confluences. In its vicinity - near Strzyża's mouth where it connects with the Vistula - there were mills, a water forge, a lumber mill, fish ponds, inns and a brewery, and potash and associated products. There were also several granges and manors and, in the hills near Jaśkowa Dolina, a picturesque landscape park with an observation point $(98 \mathrm{~m}$ a. s. I.) was established at the start of the nineteenth century. The settlements that functioned here - to the west of Gdańsk - could be reached by a number of routes, as the Grand Avenue (Grosse Allee) was delineated here as late as in the years 1768-1770 and flanked with four rows of linden trees transported from the Netherlands. Today it is Zwycięstwa Avenue and its continuation towards Oliwa - Grunwaldzka Avenue.

In 1814, Wrzeszcz and Strzyża Dolna were incorporated into Gdańsk, and subsequently the new district received rail and tram access. The nineteenth century was a period of Wrzeszcz's dynamic development - rural development was being replaced by manorial buildings and (in the central section) with several-storey townhouses, along with villa districts. At the turn of the twentieth century, the land along the Grand Avenue progressively developed, and an eclectic, Secession-style complex of the Gdańsk University of Technology was built, together with municipal cemeteries and a complex of hospital buildings (the present-day Medical Academy).

In 1929, Wrzeszcz had close to 53 thousand residents, and new townhouses and row houses were being built, while an airport was built in the Zaspa district. The Second World War brought with it a catastrophe - both in the human and material dimension. In January 1945, refugees from East Prussia reached the city and were subsequently accommodated in schools, community centres, boarding houses, etc. - shelter, medication and food was beginning to run out... Afterwards, a mass evacuation of the city's residents was performed. Regular air raids, artillery barrages and an offensive by the forces of the Second Belorussian Front initiated a spree of murder, rape and the city's nigh-utter destruction $-90 \%$ of Gdańsk's old town was destroyed! A new chapter in the life of the city began - with its mostly new residents...

Suburban and green districts and peripheral enclaves were less lucky. One such place was Jaśkowa Dolina (Jäschkenthal).

\section{RESEARCH METHOD}

The research method that allows to analyze and describe the issues of changes in the architecture of the Wrzeszcz district, especially its exposed part in the Jaśkowa Dolina area, requires the use of basic research methods in this case. The author began with field research, allowing to recognize the existing state and the scope of possible changes and the state of preservation of the most valuable objects in the study area. After this preliminary diagnosis, it was necessary to analyze the historical changes in buildings and the shaping of the park areas of the valley and surrounding hills. The observational case studies for selected objects, already described by other researchers, also brought a lot. It was also necessary to analyze the available literature and analyze internet sources, rich in numerous iconographic materials - especially historical ones. 


\subsection{Jaśkowa Dolina}

This part of Wrzeszcz is a green oasis within the city - it is a valley nudged between strips of 'green' hills. Over 200 years ago, Johan Labes, a wealthy entrepreneur and senator of the Free City of Gdańsk, purchased this land and developed it - he had trees planted, gazebos and bridges built across the local meadows and unused land and made this private park available to the residents of Gdańsk! Jaśkowa Dolina became fashionable and began attracting Gdańsk's millionaires, who began building suburban villas and small palaces in this quiet and green enclave. The later dynamic development of the entire Wrzeszcz district radically increased traffic along the street that runs through the centre of the valley.

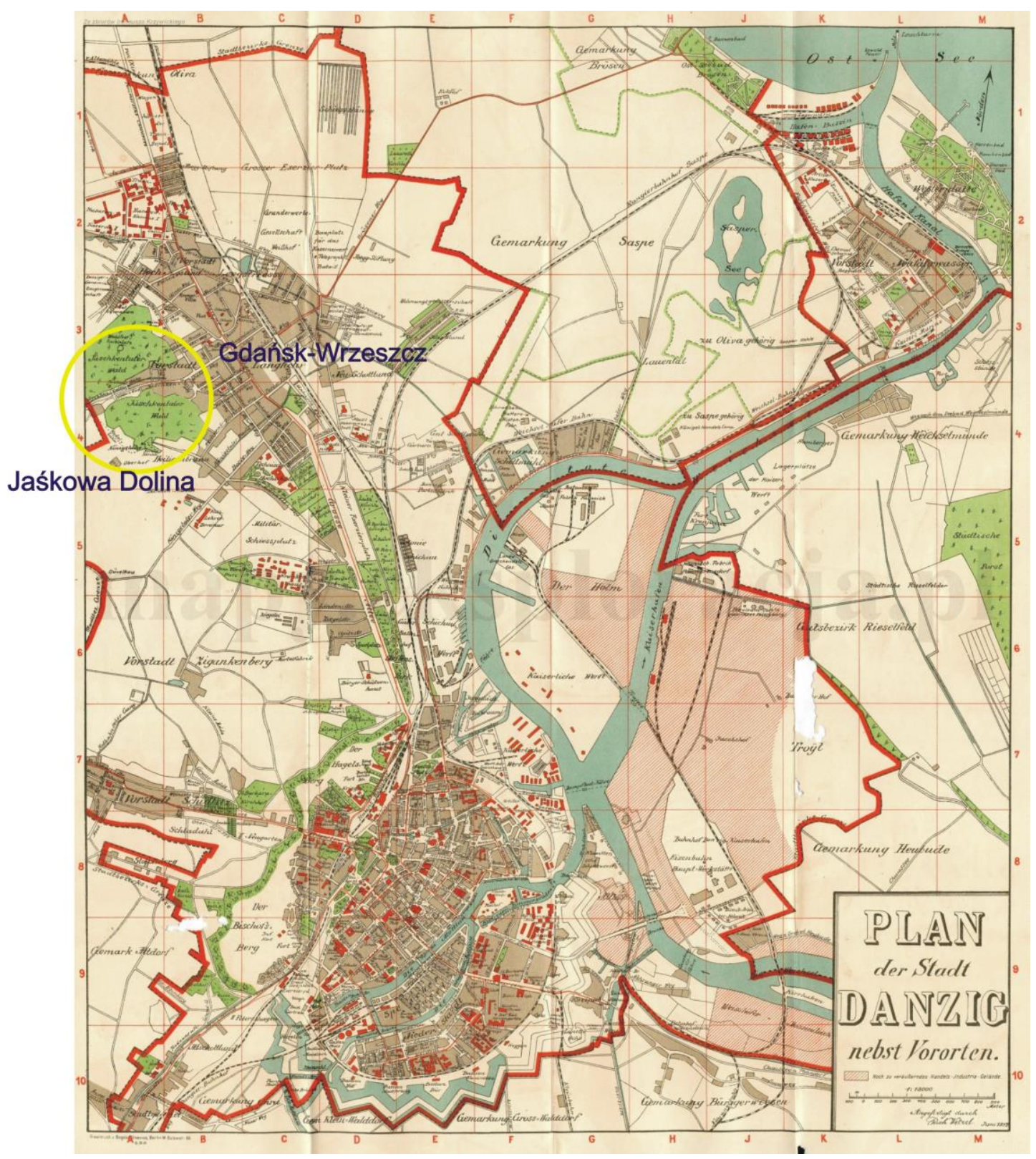

Fig. 1. Plan of Gdańsk from 1912 with the location of the area under study. Source: comp. original work, based on a map from the archives of the city of Gdańsk

Ryc. 1. Plan Gdańska z 1912 roku z lokalizacją obszaru badań. Źródło: oprac. autor na podstawie mapy z archiwum miasta Gdańska 
Today Jaśkowa Dolina - whose name is derived from the Kohne-Jaski name which owned the land in the sixteenth century - is one of the most beautiful places preserved in Gdansk. The hills and parts of the park bear the names of famous figures from Gdańsk - Johannes Hevelius (Johan Hewelcke in German) and Johannes Gutenberg. Today, the former park has the status of a municipal forest, which has been in effect since 1958, and where evening walks are no longer safe.

Fig. 2. Location of Jaśkowa Dolina (Jaśkowa Valley) on the map of the Gdańsk suburb Langfuhr from 1899. Source: archives of the city of Gdańsk. source: Plan der Vorstadt

Ryc. 2. Lokalizacja Jaśkowej Doliny na mapie przedmieścia Gdańska Langfuhr z 1899 r. larchiwum miasta Gdańsk. Źródło: Plan der Vorstadt

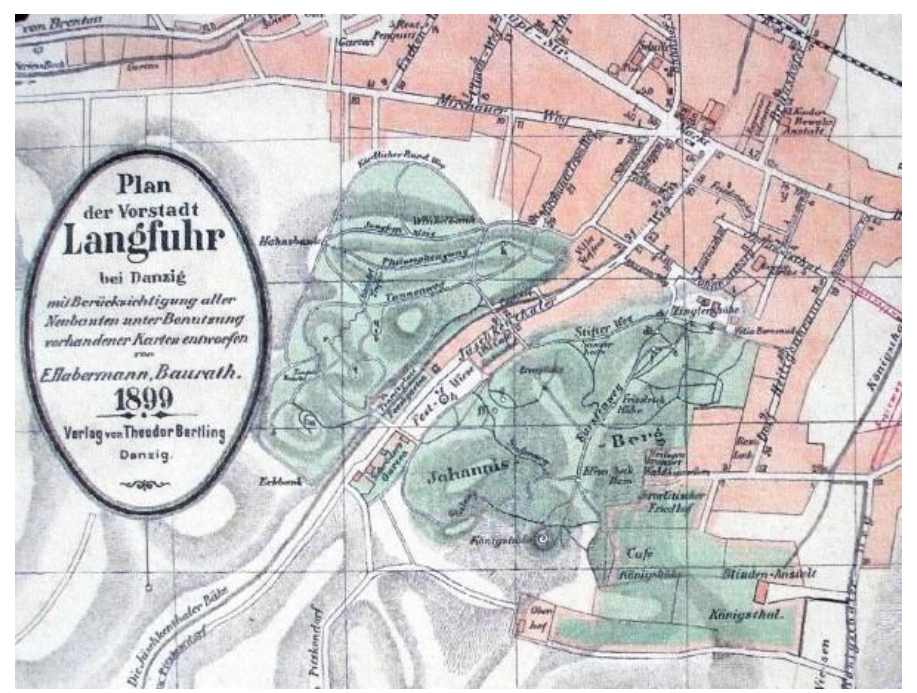

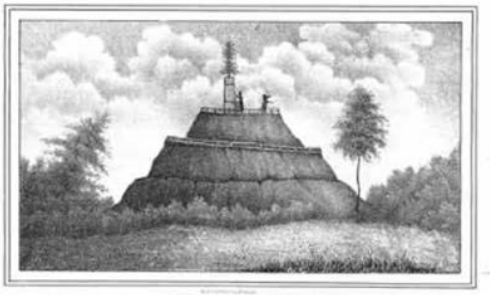

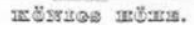

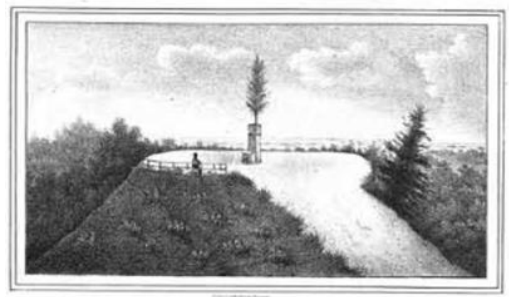

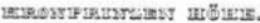

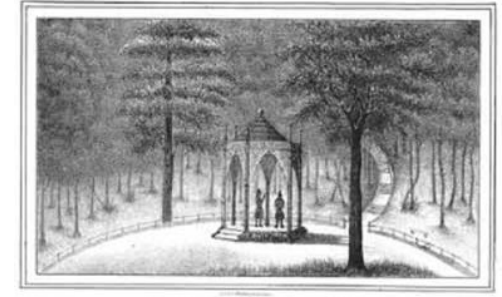

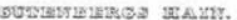

Fig. 3, 4, 5. Lithographs by Carl August Helmsauer from 1825, showing views of popular observation points in the park on the hills above Jaśkowa Dolina - from the left: Góra Królewska, Góra Książęca, Gutenberg's Grove. Source: Frąckowska A., p. 74

Ryc. 3, 4, 5. Litografie Carla Augusta Helmsauera z 1825 roku widoków popularnych punktów widokowych w parku na wzgórzach nad Jaśkową Doliną - od lewej: Wzgórze Królewskie, Wzgórze Następcy Tronu, Gaj Gutenberga. Źródło: Frąckowska A. str. 74
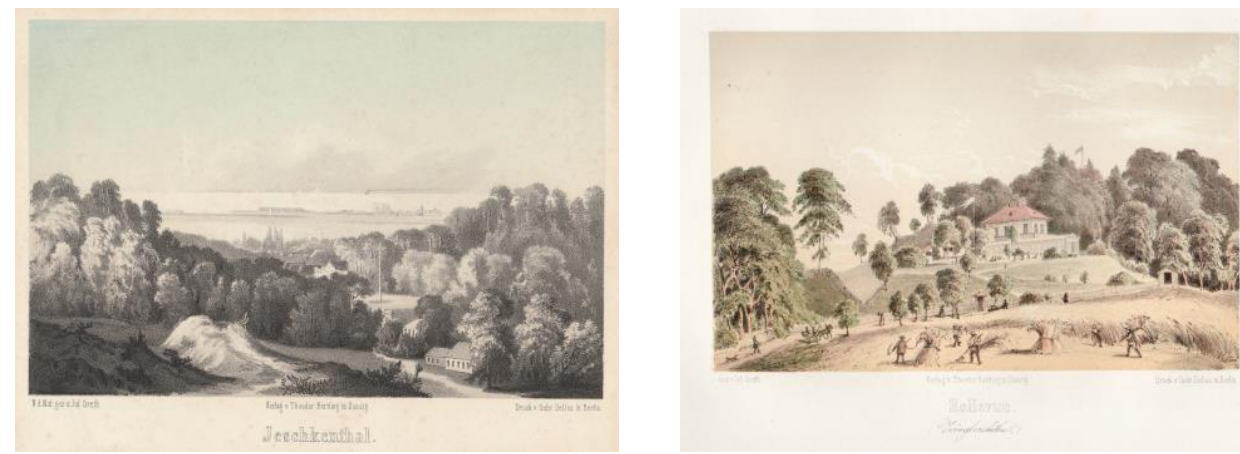

Fig. 6, 7. Lithographs by Julius Greth from around 1860 - on the left is view of the Jaśkowa Dolina, on the right is a view of the Zinglershöhe - Bellvue restaurant. Source: Artinfo.

Ryc. 6, 7. Litografie Juliusa Gretha z ok. 1860 r. - po lewej widok na Jaśkową Dolinę, z prawej widok na restaurację Zinglershöhe - Bellvue. Źródło: Artinfo. 

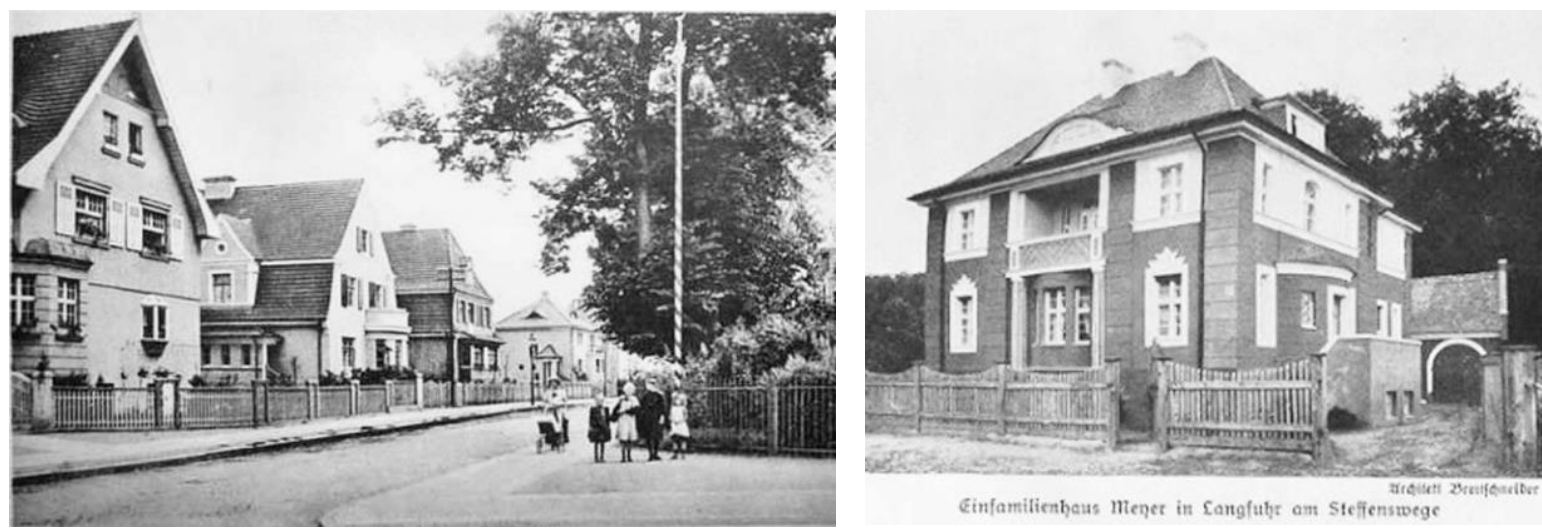

Fig. 8, 9. Gdańsk-Wrzeszcz, residential buildings - early twentieth century Source: Przewodnik po Gdańsku Ryc. 8, 9. Gdańsk-Wrzeszcz, zabudowa willowa - pocz. XX w. Źródło: Przewodnik po Gdańsku

\subsection{Villas from the turn of the twentieth century}

At the turn of the twentieth century, Jaśkowa Dolina (Wrzeszcz Górny) was attracting increasing numbers of Gdańsk's residents, traders and manufacturers - even from Łódź and Bydgoszcz, who built their suburban villas here, utilises the nearby meadows and visually appealing slopes of nearby hills. This part of Wrzeszcz, due to attractive landscape conditions, was becoming increasingly fashionable - the parcels around this road became the sites of eclectic villas with gardens. Similar eclectic forms and details were given to multi-family townhouses erected along a main street (Jäschkenthaler Weg) that ran along the bottom of the valley. After the Second World War, the villas and townhouses that had been deserted by Germans were taken over by new residents, who would not identify themselves with this heritage until many years later and who did not pay much attention to its proper maintenance.

\subsection{Major surviving buildings}

Today, a part of the surviving buildings has once again changed hands and been subjected to renovation and revitalisation, while others - unfortunately - remain in the hands of uncaring owners and rapidly deteriorate.

45 Jaśkowa Dolina Street. Near to the entrance of the former Johan Labes park there is a wooden villa built in 1884 in the Swiss-Tirol style - a former forester's lodge (Forsthaus in German), which later housed a restaurant and is currently 'simply' a residential building.

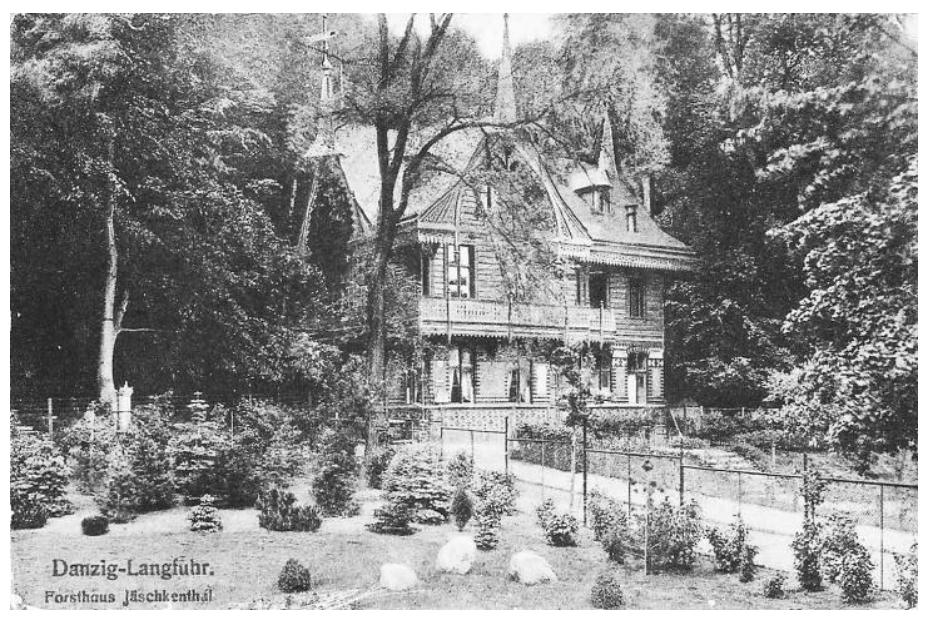

Fig. 10. Gdańsk-Wrzeszcz (Danzig-Langführ) building of the former forester's lodge (Forsthaus). Source: fotopolska.eu

Ryc. 10. Gdańsk-Wrzeszcz (DanzigLangführ), budynek dawnej leśniczówki (Forsthaus). Źródło: fotopolska.eu 

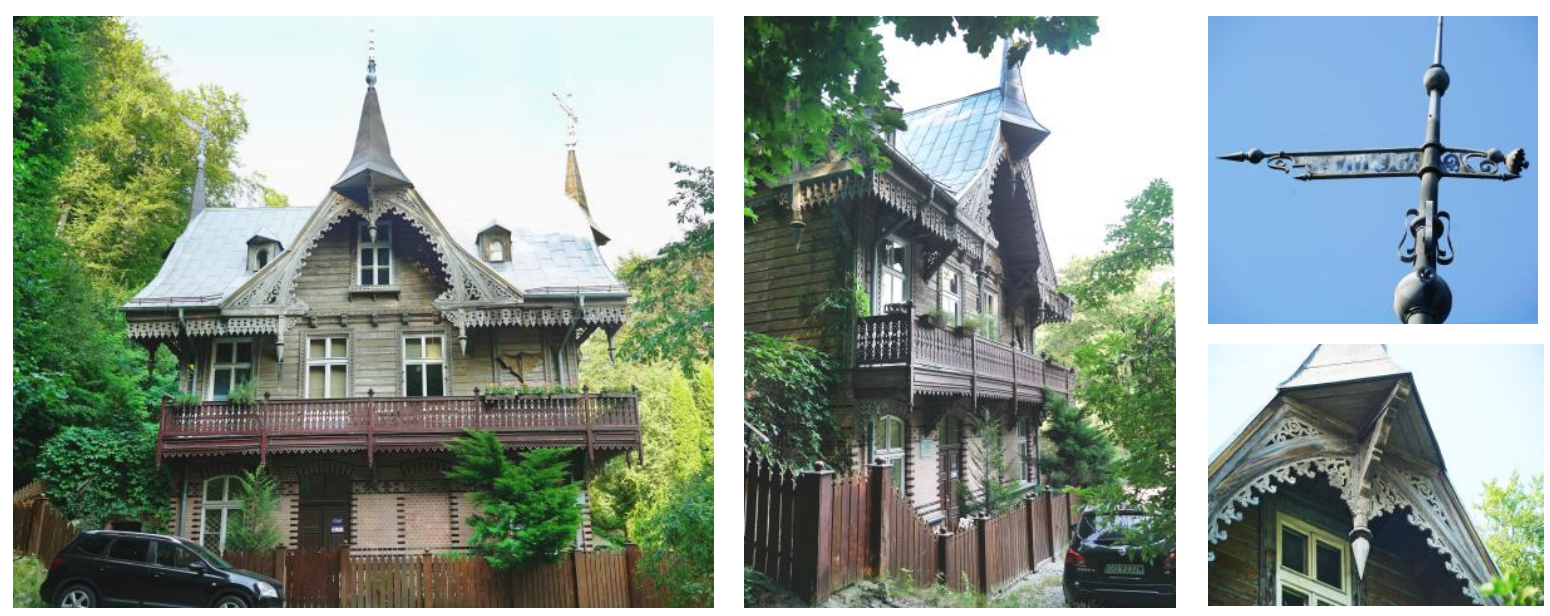

Fig. 11, 12, 13, 14. Gdańsk-Wrzeszcz (Danzig-Langführ), building and detail of the former forester's lodge (Forsthaus). Source: original photos 2020

Ryc. 11, 12, 13, 14. Gdańsk-Wrzeszcz (Danzig-Langführ), budynek i detale dawnej leśniczówki (Forsthaus). Żródło: fotografie autora 2020
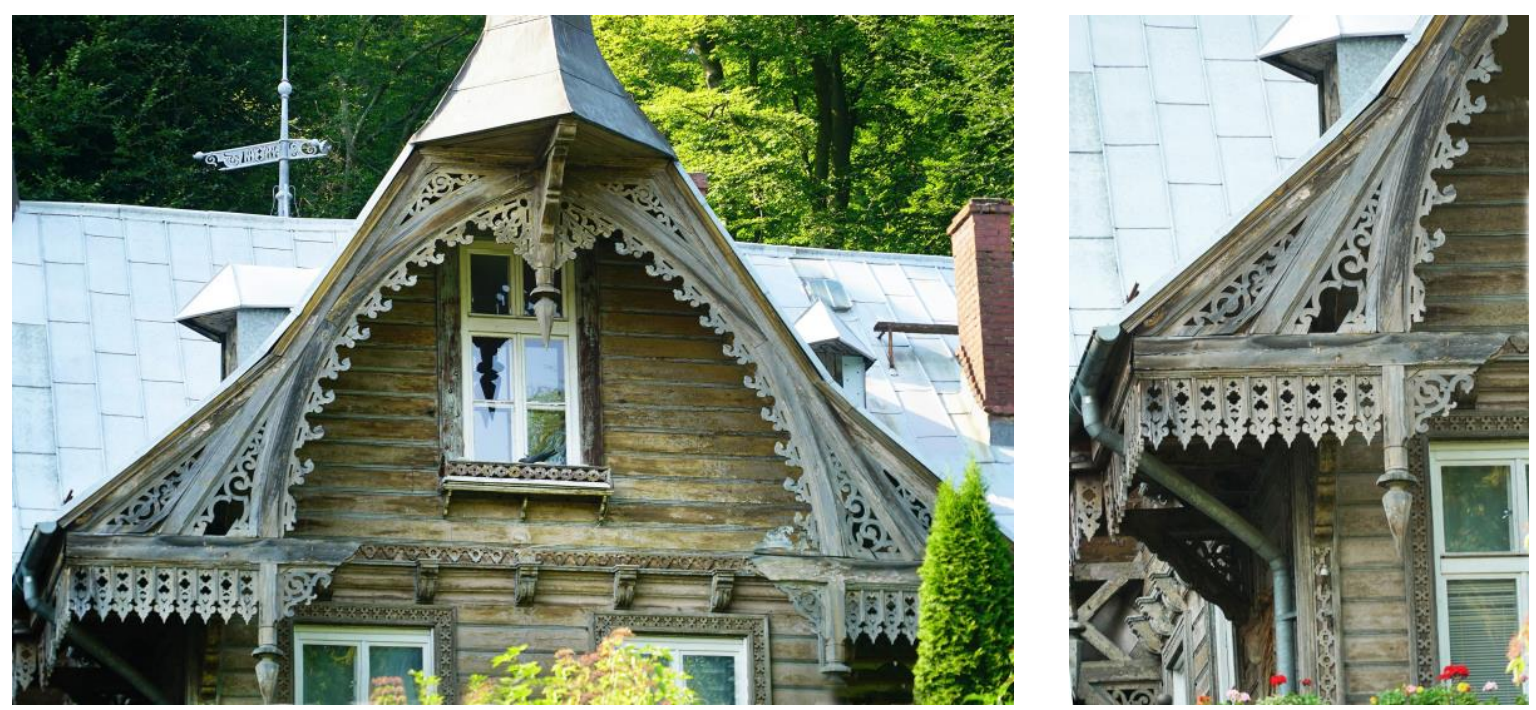

Fig. 15, 16. Gdańsk-Wrzeszcz (Danzig-Langführ), decorative details of the former forester's lodge (Forsthaus). Source: original photos 2020

Ryc. 15, 16. Gdańsk-Wrzeszcz (Danzig-Langführ), detale zdobnicze dawnej leśniczówki (Forsthaus). Źródło: fotografie autora 2020

44 Jaśkowa Dolina Street - the Kirsch Villa. It was built in 1856 and has been a listed heritage building since 1995. In the years 1994-2007 it housed the General Consulate of Ukraine. Today, the villa is a private property and has undergone general renovation. Its redesigned garden has received several international awards - including winning the A'design Award \& Competition and the Design Award 2015 Los Angeles. 

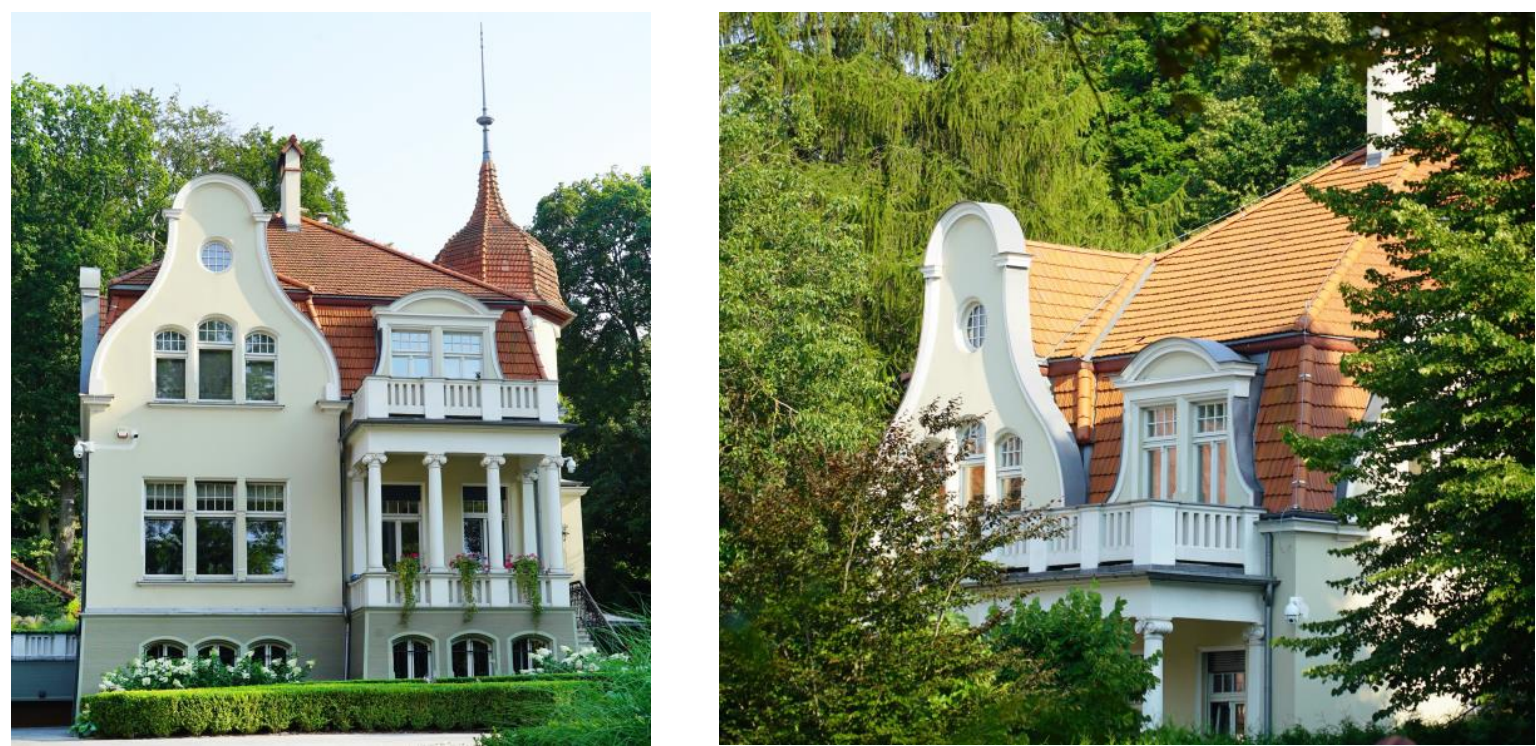

Fig. 17, 18. 44 Jaśkowa Dolina Street - the Kirsch villa, after a general renovation, the building regained its former splendour. Source: original photos 2020

Ryc. 17, 18. Ulica Jaśkowa Dolina 44 - willa Kirsch, po generalnym remoncie budynek odzyskał dawny blask. Źródło: fot. autor 2020

31 Jaśkowa Dolina Street - the Freymann Villa. Built by Caspar Freymann, a trader in handicrafts and attire, in 1902. In 1920, the villa was the property of the Baltic Bank, and after 1924 it became the property of Luis Luchtenstein, a factory owner and later consul of the Republic of Haiti. In 1942 it came into the hands of Helmut Koschnik, a wood trader. At present, it is a branch of the Polish Academy of Sciences.
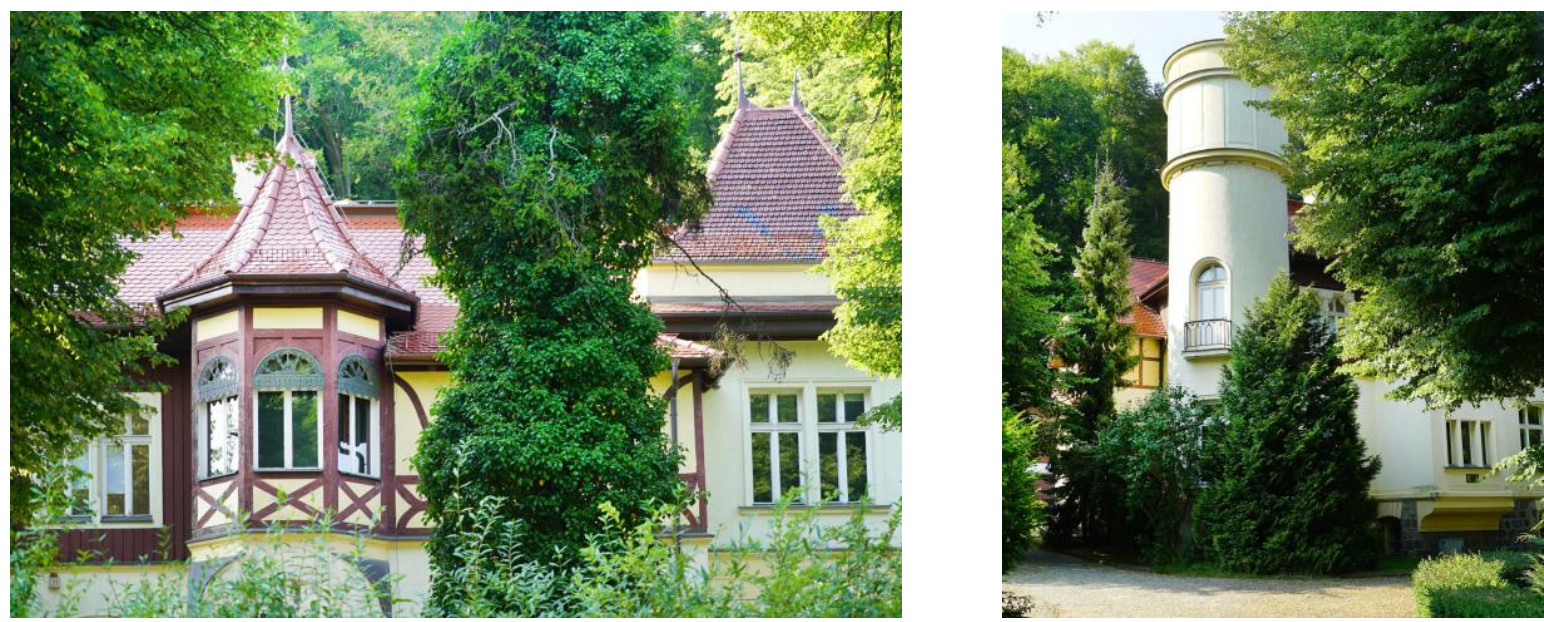

Fig. 19, 20. 31 Jaśkowa Dolina Street - the Freymann Villa, now a branch of the Polish Academy of Sciences is located here. Source: original photo 2020

Ryc. 19,20. Jaśkowa Dolina 31 - Willa Freymann, obecnie ma tu siedzibę Polsk Akademia Nauk. Źródło: fot. autor 2020

19 Jaśkowa Dolina Street - the Schrey Villa. Built in 1899, it was the property of the owner of a train car factory - Otto Schrey. Its austere appearance makes it slightly mysterious. 

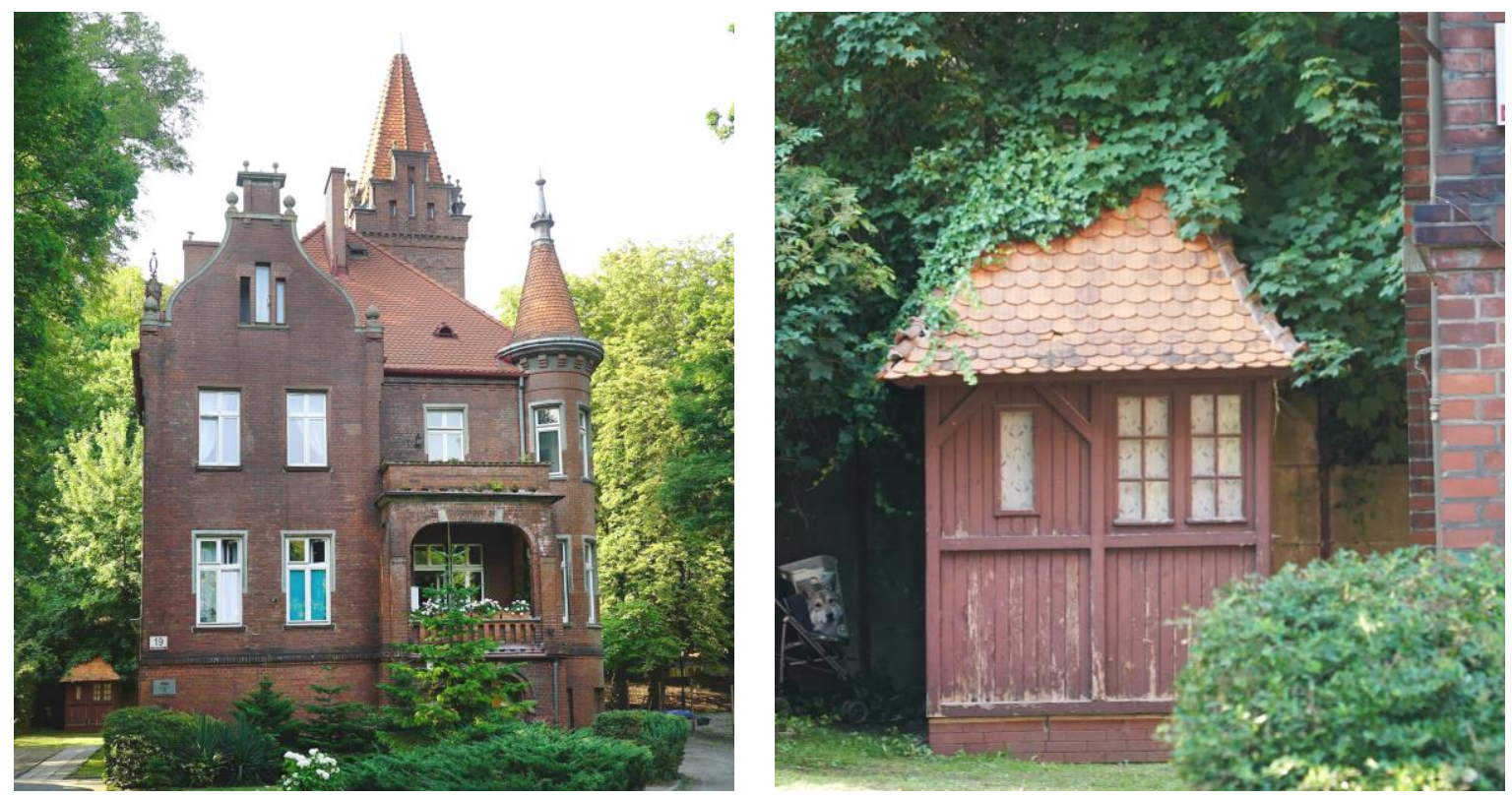

Fig. 21, 22. 19 Jaśkowa Dolina Street - the Schrey Villa. Villa facade and utility pavilion. Source: original photo 2020 Ryc. 21, 22. Jaśkowa Dolina 19 - Willa Schrey. Fasada oraz pawilon gospodarczy. Źródło: fot. autor 2020

2A Pawłowskiego Street - the Gollner (Henkenhaf) villa. It was built in 1902 - the fairy-tale architecture of this house immediately attracts the gaze of passersby, and its appearance has largely remained unchanged. Even the windows, replaced with contemporary, double-glazed ones, has maintained their 'pattern', i.e. formal division.
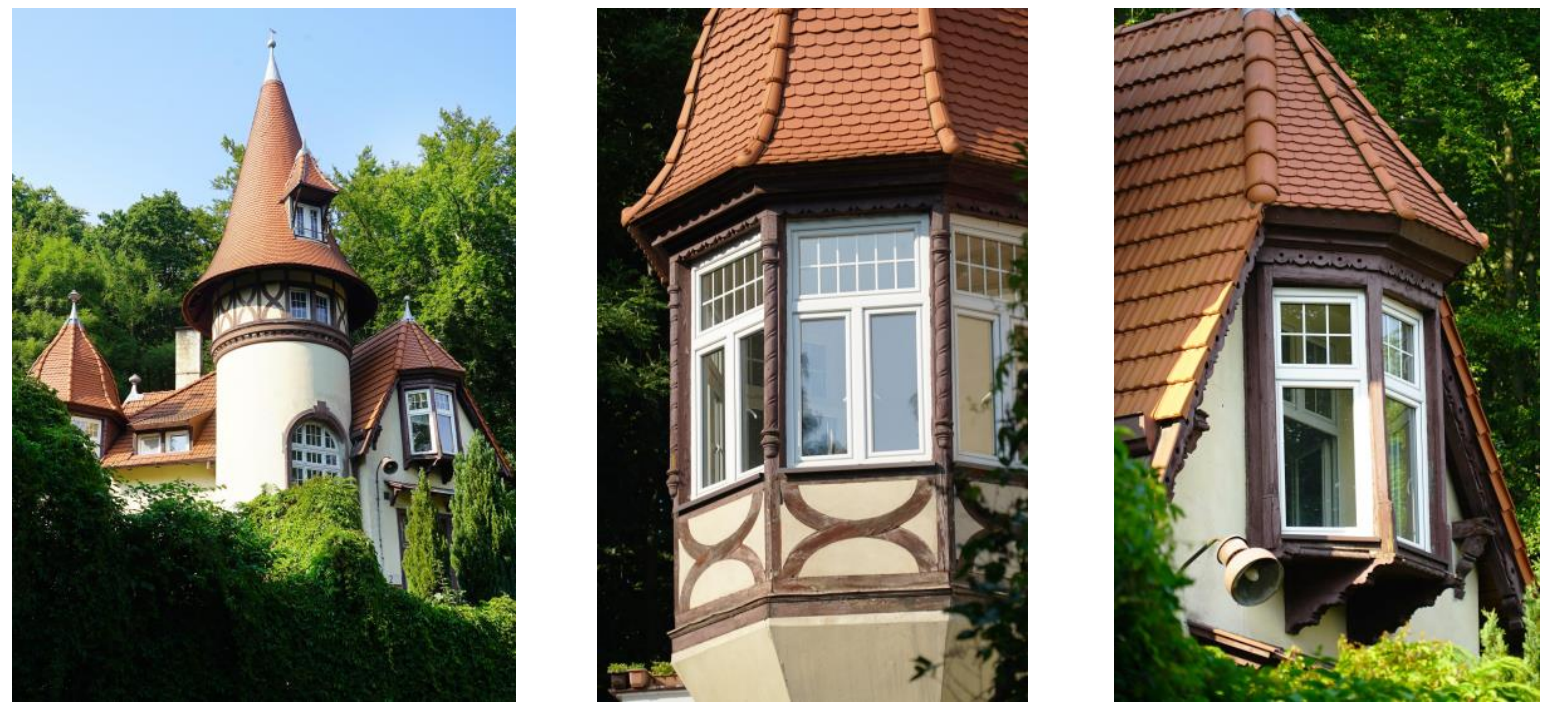

Fig. 23, 24, 25. 2A Pawłowskiego Street - Gollner-Hernkenhaf, facade and details of the bay window. Source: original photo 2020

Ryc. 23, 24, 25. Pawłowskiego 2A - Willa Gollner-Hernkenhaf, fasada i detale wykuszy. Źródło: fot. autor 2020

3 Pawłowskiego Street - an eclectic villa built in 1899, it has a half-timbered structure in its attic section and reserved detail formed in plaster. After renovation, the entirety is in good technical condition today. 

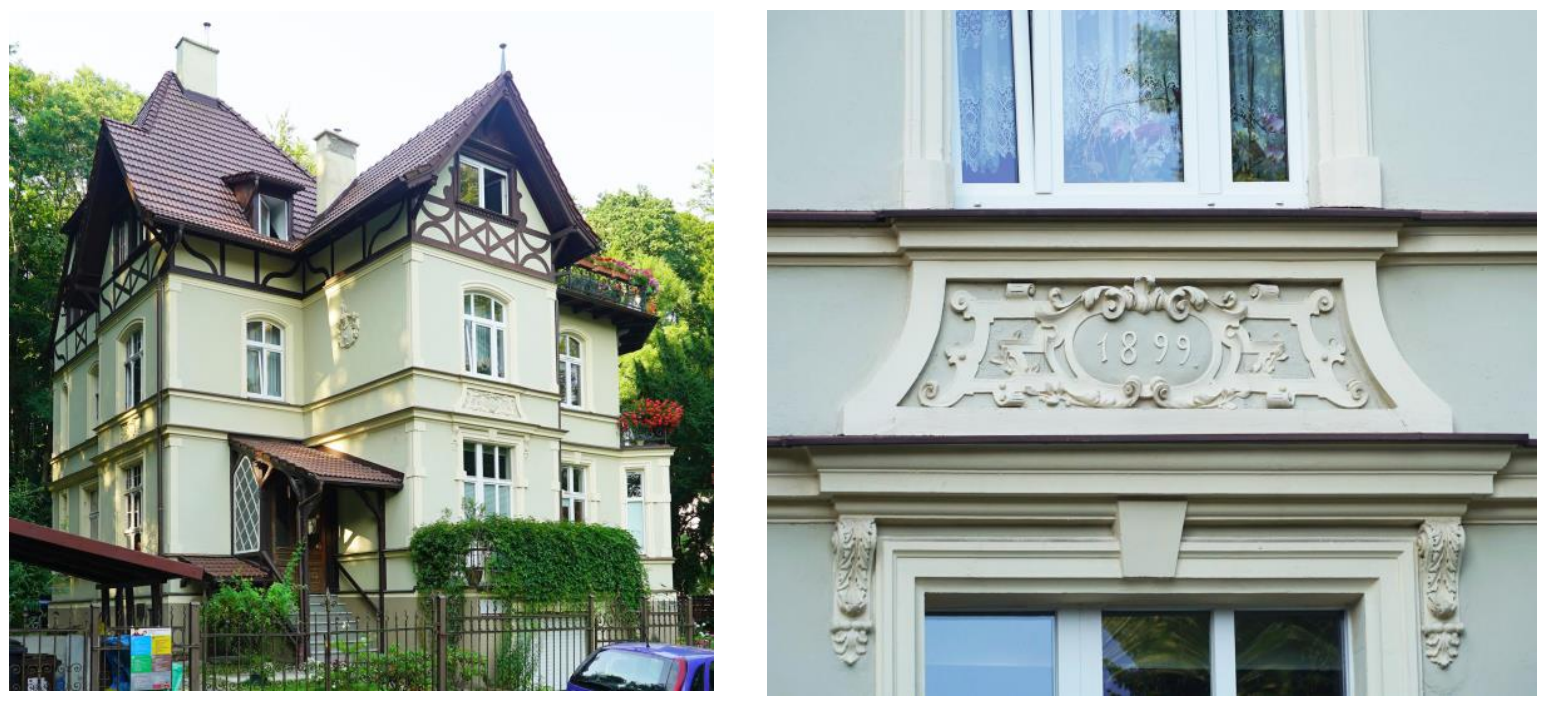

Fig. 26, 27. 3 Pawłowskiego Street. Eclectic villa from 1899. Source: original photo 2020

Ryc. 26, 27. Pawłowskiego 3. Eklektyczna willa z 1899 r. Źródło: fot. autor 2020

1A Pawłowskiego Street - yet another eclectic villa from the turn of the twentieth century. It offers apartments for rent/sale that are $4 \%$ more expensive than in the centre of the district. The roof has been renovated, yet the earlier gutter blockage has damaged the external plasters of the frontal facade. The villa, similarly as its neighbouring building, has had its windows replaced with modern, double-glazed window sets. The front door is original - made of wooden panels and equipped with a fanlight. The villa operates with structural and decorative elements typical of the period of its construction - with highlights of the outline of the gable's half-timber structure.
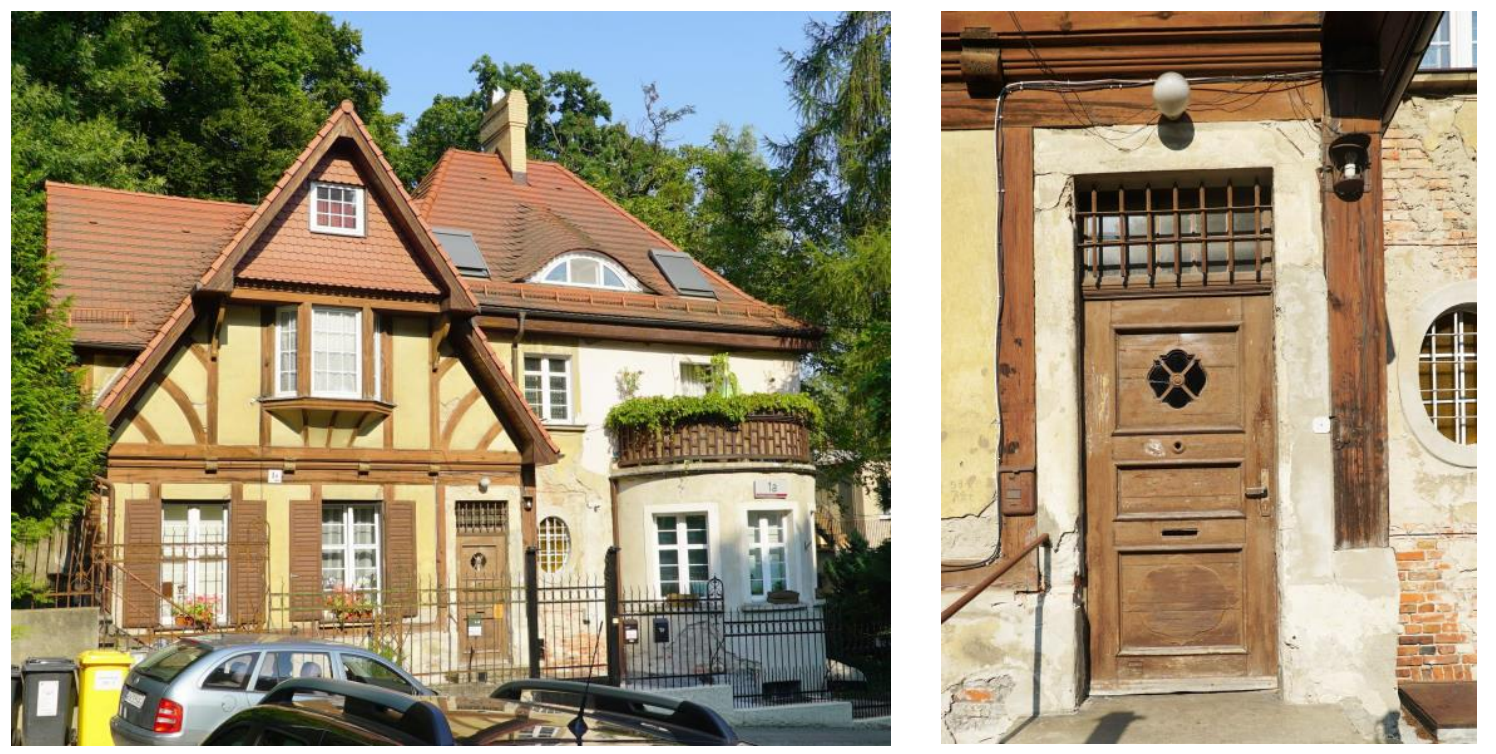

Fig. 28, 29. Pawłowskiego 1A Street - a villa from the turn of the twentieth century, facade and detail of the front door. Source: original photo 2020

Ryc. 28,29. Ulica Pawłowskiego 1A - willa z przełomu XIX i XX wieku, fasada i detal drzwi wejściowych. Źródło: fot. autor 2020 
14 Sobótki Street - former Café Zinglershöhe and Villa Litewski. This street, which connects Jaśkowa Dolina and Matejki streets with a wide arc, leads to, among other places, the remains of the former Zingler Café and its neighbouring villa of Doctor Michał Litewski. In 1843, on a hill called John's Mount (Joannisberg), Gdańsk trader Zingler built an inn in the Swiss style (Gasthaus) which was originally called Bellevue (Beautiful Veiw). However, it was the common name of the restaurant and hill that became widely used - Zinglerhohe (Zingler Hill). Twenty-five ears layer, the restaurant has been extended to include a glazed terrace - a veranda. The restaurant changed hands several times and was subjected to many remodelling procedures. In the years 1925-1933 the building was owned by a Freemason Lodge. It was closed towards the end of 1941.
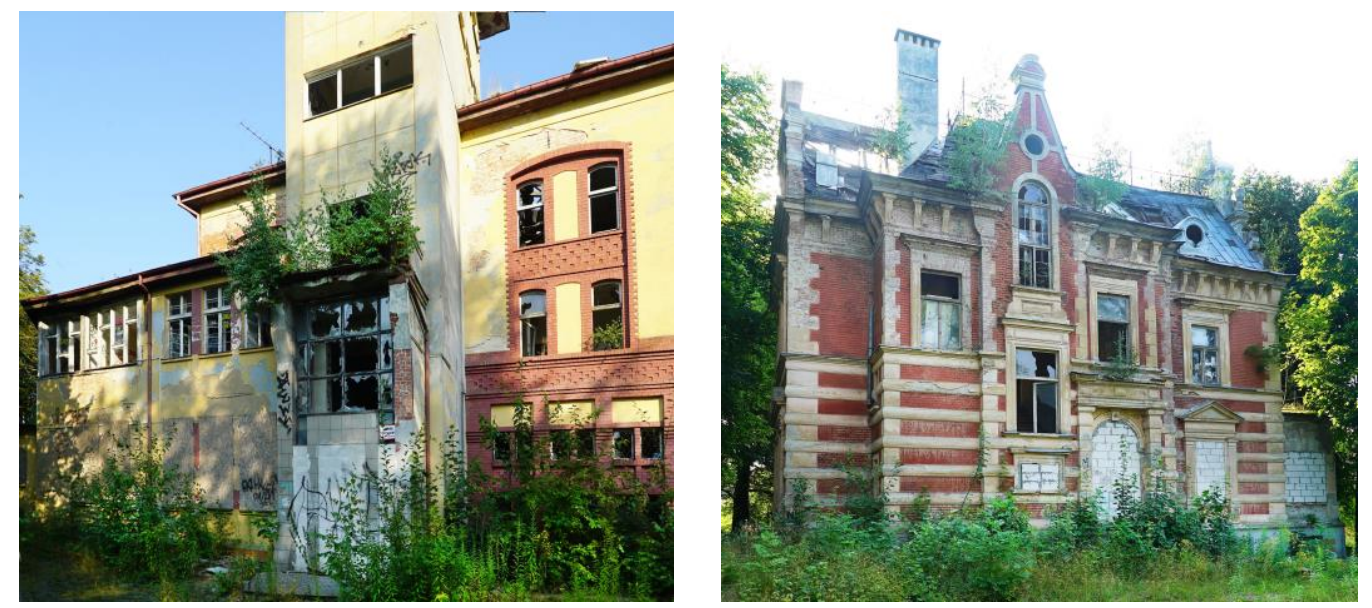

Fig. 30, 31. 14 Sobótki Street - remains of buildings abandoned by TVP Gdańsk: Zingler Cafes (on the left) and Villa Litewski. Source: original photo 2020

Ryc. 30, 31. Ulica Sobótki 14 - pozostałości budynków opuszczonych przez TVP Gdańsk: kawiarni Zinglera (po lewej) i Villi Litewski. Źródło: fot. autor 2020
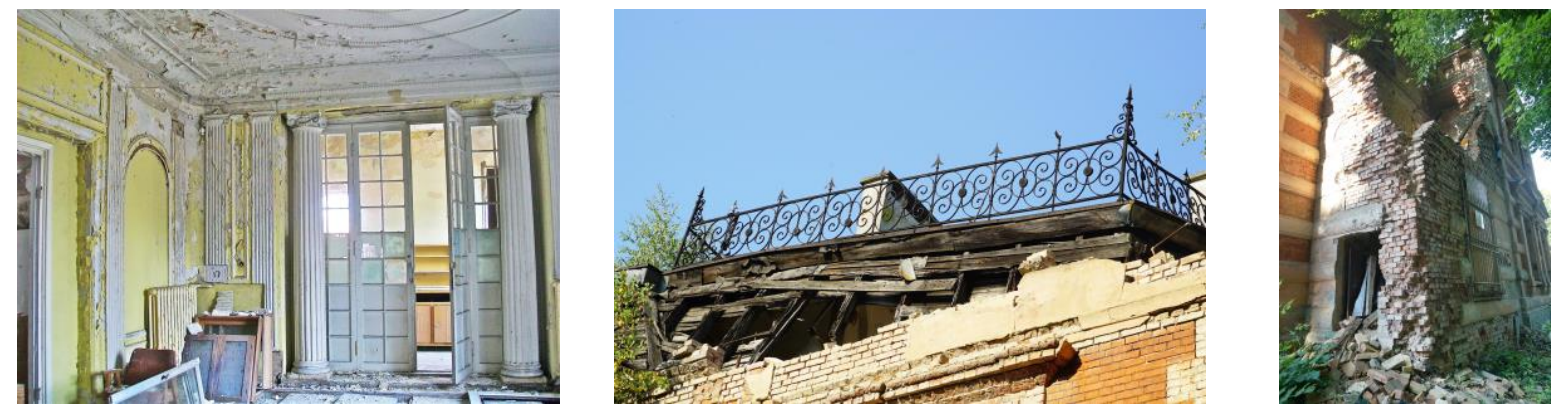

Fig. 32, 33, 34. Deteriorated and ruined building of the former Villa Litewski. /interiors. Source: Frąckowska A., 2019, photos 33 and $34-$ by the author

Ryc. 32, 33, 34. Zdewastowany i zrujnowany budynek dawnej Willi Litewski. /wnętrza. Źródło: Frąckowska A., 2019, fot. 33 i 34 - autor

After the Second World War, the building housed a dancing club (Cyganeria), and after a renovation in 1950 it acted as a community centre - with a cinema and a coffee shop. In 1959, the restaurant, along with the neighbouring Villa Litevski, became the property of the TVP Gdańsk television broadcaster. After it moved to a new building in 1996, both buildings have started to rapidly deteriorate. Last year, the building's new owner - a real estate development company, declared the con- 
struction of several apartment buildings, intended to 'match' the character of the surroundings and traditions of Jaśkowa Dolina... The existing buildings, which are under conservation (the villa and a section of the former restaurant) shall (reportedly) be thoroughly renovated - unfortunately, after years of neglect, numerous elements of the structure, detail, finishes and furnishings (primarily in the villa) have been irreparably damaged.

5 Pawłowskiego Street - townhouse from the turn of the twentieth century. At present, the building is used by a housing community and inhabited by several families. The building has a compact massing, freshly replaced cladding and windows. It is clearly visible from the street and accessible. Unfortunately, cracks in the external walls can be a sign of its weak foundations or irregularities in soil hydrological conditions. The internal and external doors, as well as the stairs and floors, are original. The facade features plaster mouldings with floral motifs. The frontal corner is decorated by a sculpture of Diana.
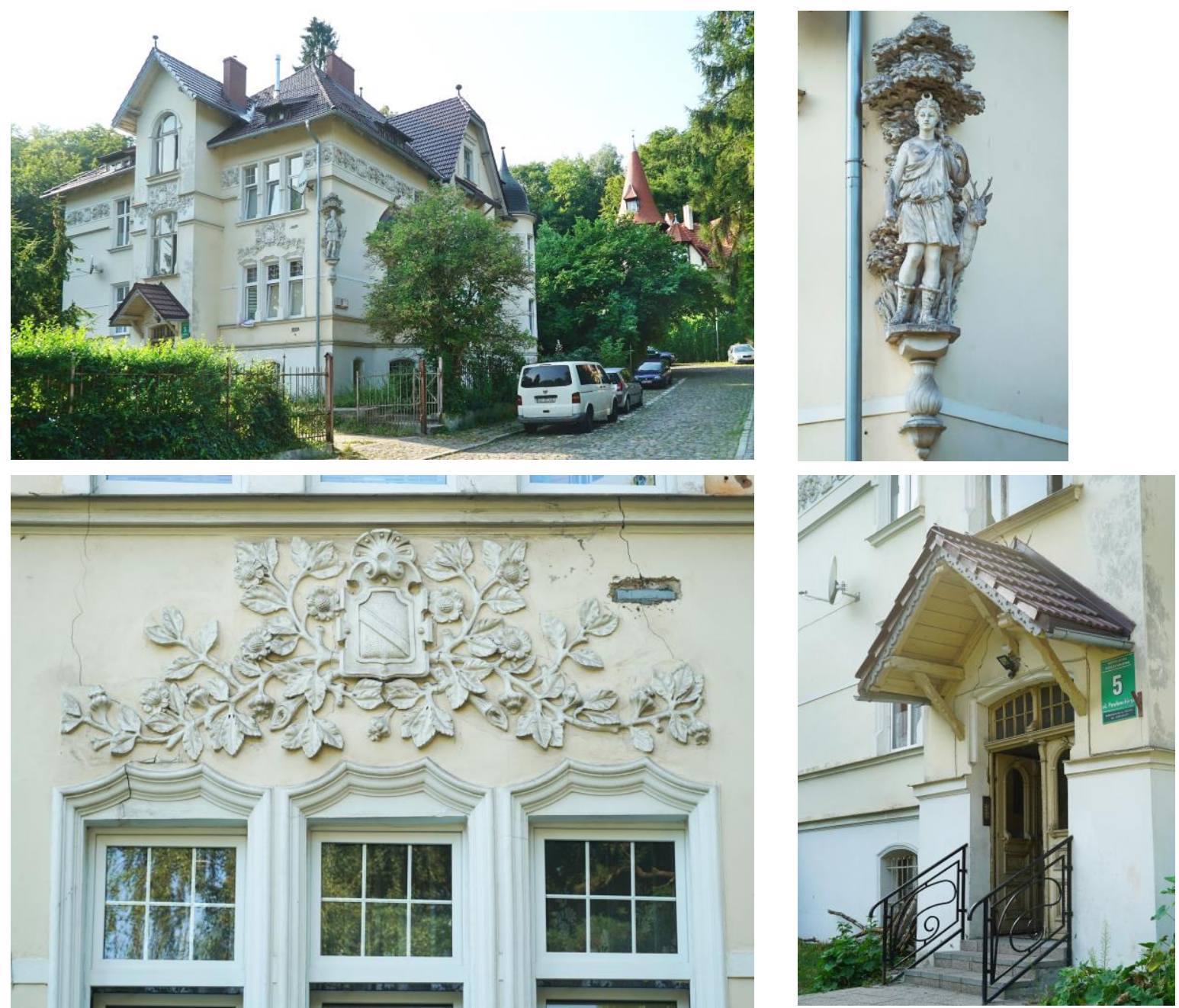

Fig. 35, 36, 37, 38. General view and details of the townhouse at 5 Pawłowskiego Street. Source: original photo/ Ryc. 35, 36, 37, 38. Widok ogólny i detale kamienicy przy ul. Pawłowskiego 5. Żródło: fot. autor/

6 Batorego Street - tenement house. It is a three-storey building, whose two uppermost storeys have a half-timbered structure. It is a multi-family building, where the structure of the wooden frame plays an important decorative role - highlighted by the colour of its elements. The facade, which is 
not visible from the street, shows signs of considerable conservatorial neglect - roof tiles and elements of the drainage system are missing.
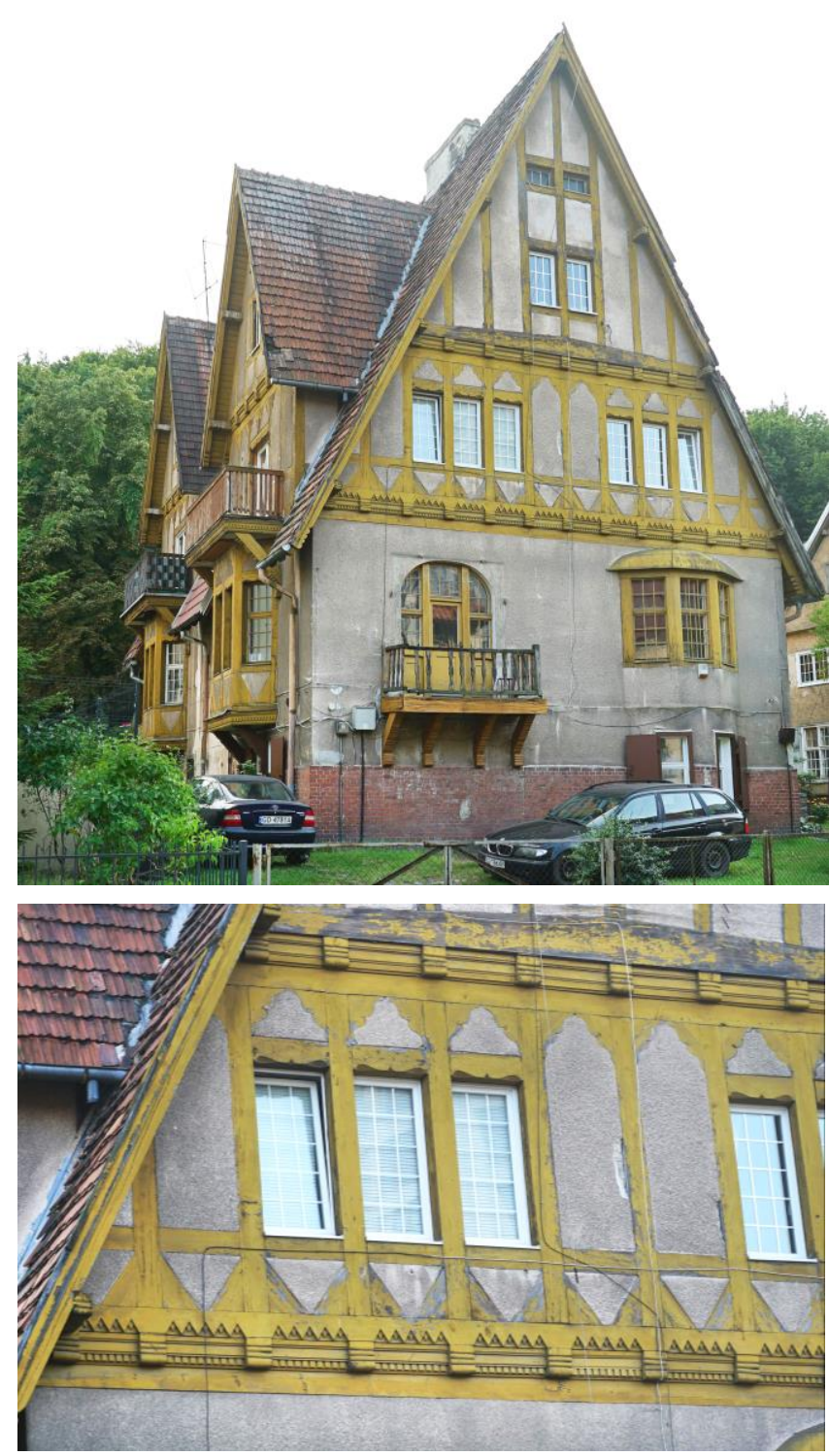
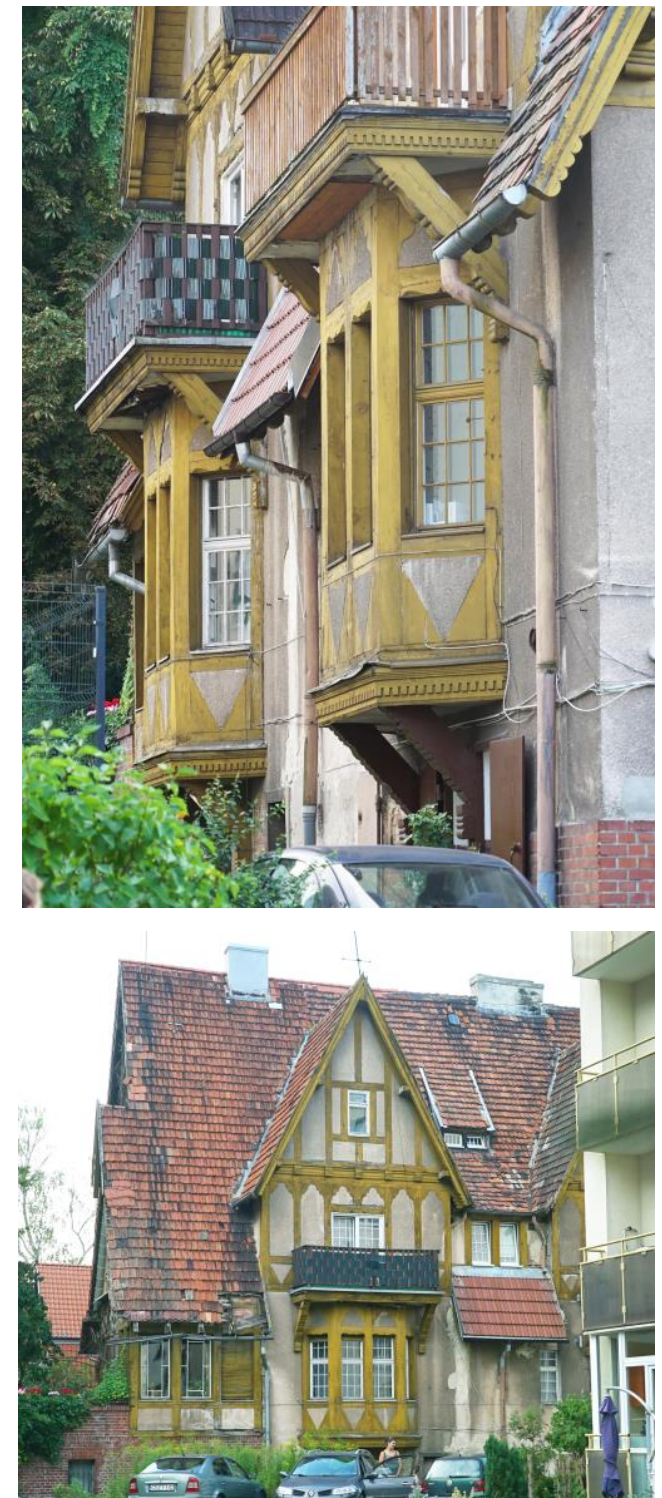

Fig. 39, 40, 41, 42. General view and details of the tenement house at 5 Pawłowskiego Street. Source: original photo Ryc. 39, 40, 41, 42. Ulica Batorego 8, kamienica czynszowa z przełomu XIX i XX wieku - widoki ogólne i detale konstrukcji drewnianej. Źródło: fot. autor 2020

\section{CONCLUSIONS}

Today, the villa architecture and townhouses of Górny Wrzeszcz from the turn of the twentieth century constitutes a testimony of the financial wealth and aspirations of burghers, the intelligentsia, traders and entrepreneurs of the Free City of Gdańsk. Participation in global maritime trade and ties with the Prussian state formed the basis for the development of the city and the region. In ar- 
chitecture, this resulted in constructing industrial buildings, the development of circulatory infrastructure, public buildings as well as residential ones - both large and small.

The majority of projects from this period are eclectic details and forms. It was the beginnng of the twentieth century that brought with it simplified forms, subjected to a different design logic and assumptions. It can be said that the power of tradition and the classical education of architects, obtained at German universities and in Vienna, nevertheless prevailed. Compilations of various historical motifs made their mark across Europe and the rest of the world, proving the strength of tradition and habit, as well as the rank of previous aesthetic canons.

As a result, the contemporaneous world of 'civilised' forms (done so by designers) was seen as almost fairy-tale-like, in which form and the ornament that decorated it were an extension of a world of childhood dreams. Today, it turns out that after over 120 years, these forms are still attractive just as the 'colours and flavours' of childhood are. It is no wonder then, that successive generations of users and audience members are swayed by this architecture. Wartime operations spared most of the suburban development of Gdańsk, Oliwa and Sopot. Unfortunately, the total replacement of owners was not fortunate to some. Today, many buildings - both townhouses and tenements show a considerable degree of technical deterioration. The 'best' example of this is the complex of buildings that was abandoned by TVP Gdańsk at John's Mount, at 14 Sobótki Street. Unfortunately, on the national scale, there are more than enough similar cases.

Seventy-five years have passed since the wartime disaster - Gdańsk's Old Town has been rebuilt and suburban areas slowly regain their former charm. The beauty of Jaśkowa Dolina - its landscape attractiveness and architectural gems - currently deserve special protection so as not to lose their previous value. However, there is the threat of - unfortunately - predatory real estate development that ignores tradition and the legacy of generations past. This is why Jaśkowa Dolina together with its adjoining green areas and other similar areas of the Tri-city - should be placed under conservation - and deservedly so.
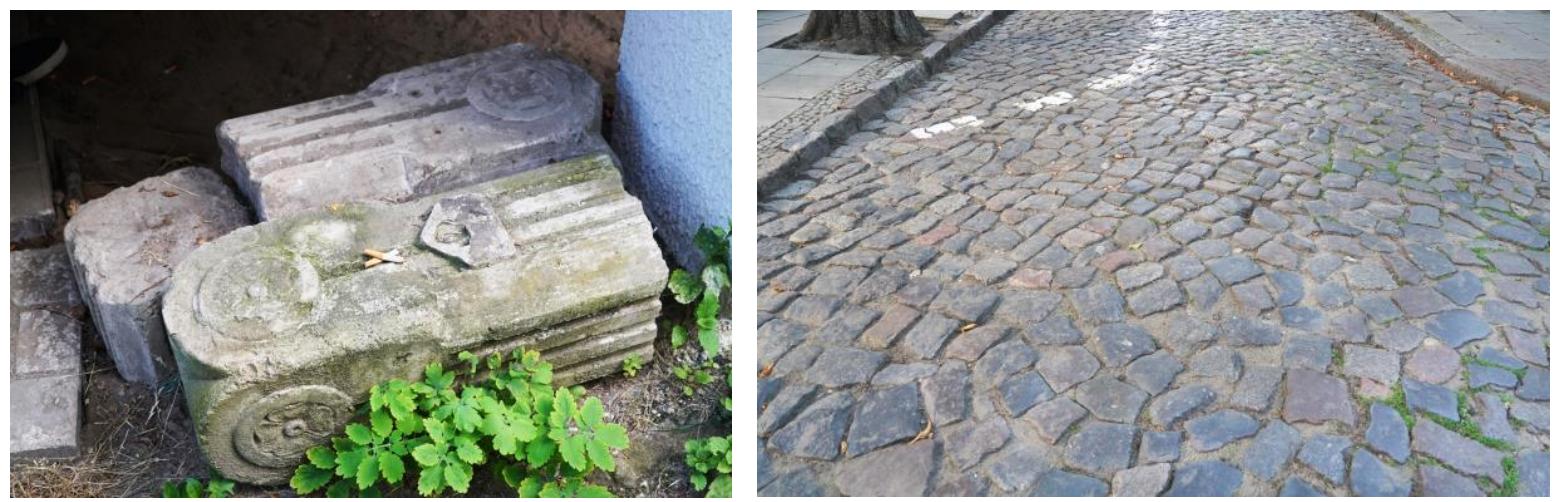

Fig. 43,44. Relics of the remains of construction activities in Gdańsk-Wrzeszcz - on the left at Batory street, on the right at Sobótka street. Source: original photo

Ryc. 43,44. Relikty pozostałości działalności budowlanej w Gdańsku-Wrzeszczu - po lewej przy ul. Batorego, po prawej na ul. Sobótki. Źródło: fot. autor 2020 


\title{
DAWNYCH WSPOMNIEŃ CZAR - ARCHITEKTURA WILLOWA JAŚKOWEJ DOLINY W GDAŃSKU-WRZESZCZU
}

\begin{abstract}
Było sobie kiedyś miasto, które obok przedmieść Orunia, Siedlce, Oliwa, Emaus, Pruszcz, Święty Wojciech, Młyńska i Nowy Port miało przedmieście o nazwie Wrzeszcz. Wrzeszcz był tak duży i tak mały, że wszystko, co na tym świecie wydarza się lub mogłoby się wydarzyć, wydarzyło się lub mogłoby się wydarzyć we Wrzeszczu.
\end{abstract}

/Gunter Grass „Psie Lata”|

\section{WSTĘP}

Jedną z najstarszych dzielnic Gdańska jest Wrzeszcz (niem. Langführ). Pierwsza wzmianka o niej pochodzi z roku 1263 jako o niewielkiej osadzie w pobliżu Gdańska. Życie ówczesnych mieszkańców skupiało się na rzece Strzyża (Strieß) i jej dopływach. W tej okolicy - przy ujściu Strzyży do Wisły funkcjonowały młyny, kuźnia wodna, tartak, stawy rybne, gospody i browar, wyrabiano potaż i wajdaż, powstało także kilka folwarków i dworów, a na wzgórzach obok Jaśkowej doliny w pocz. XIX wieku utworzono malowniczy park krajobrazowy z punktem widokowym (98 m n.p.m.). Do funkcjonujących tu - po zachodniej stronie Gdańska - osad dojeżdżało się kilkoma traktami i dopiero w latach 1768-1770 wytyczono Wielką Aleję (Grosse Allee), którą obsadzono czterema, sprowadzonymi z Holandii, rzędami lip. Dziś jest to Al. Zwycięstwa i jej kontynuacja w kierunku Oliwy - Al. Grunwaldzka.

W roku 1814 Wrzeszcz i Strzyżę Dolną przyłączono do Gdańska z którym dzielnica ta uzyskała następnie połączenie kolejowe i tramwajowe. Wiek XIX był okresem dynamicznego rozwoju Wrzeszcza - zabudowa wiejska zastępowana była zabudową dworkową i (w części centralnej) kilkukondygnacyjnymi kamienicami, powstawały również dzielnice willowe. Na przełomie XIX i XX wieku postępowało zagospodarowanie terenów przy Wielkiej Alei, wybudowano eklektycznosecesyjny zespół Politechniki Gdańskiej, cmentarze miejskie i kompleks budynków szpitalnych (obecnie Akademia Medyczna).

W 1929 roku Wrzeszcz liczył blisko 53 tys. mieszkańców, budowano nowe kamienice i domy w zabudowie szeregowej, a w dzielnicy Zaspa powstało lotnisko. II wojna światowa przyniosła miast swoistą katastrofe - tak w wymiarze ludzkim jak i materialnym. W styczniu 1945 roku dotarli do miasta uchodźcy z Prus Wschodnich, których lokowano w szkołach, świetlicach, internatach itp. - zaczynało brakować schronów, lekarstw i jedzenia... Potem nastapiła masowa ewakuacja mieszkańców miasta. Regularne naloty, ostrzał artyleryjski i atak wojsk 2 Frontu Białoruskiego rozpoczęły się mordy i gwałty, i unicestwianie miasta - starówka gdańska została zniszczona w 90 procentach! Rozpoczął się nowy rozdział w życiu miasta - z jego, w większości nowymi, mieszkańcami...

Nieco więcej szczęścia miały dzielnice podmiejskie i ich zielone, peryferyjne enklawy. Miejscem takim m.in. była tzw. Jaśkowa Dolina (Jäschkenthal).

\section{METODA BADAŃ}

Metoda badawcza pozwalająca na analizę i opisanie problematyki zmian w architekturze dzielnicy Wrzeszcz, a zwłaszcza jej wyeksponowanej części na obszarze Jaśkowej Doliny, wymaga - w tym przypadku - zastosowania podstawowych metod badawczych. Autor zaczął od badań terenowych, pozwalających rozpoznać stan istniejący i zakres możliwych zmian oraz stan zachowania najcenniejszych obiektów na badanym obszarze. Po tej wstępnej diagnozie konieczna była analiza historycznych zmian w zabudowie i ukształtowaniu terenów parkowych doliny i otaczających ją wzgórz. Sporo wniosły też obserwacyjne studia przypadków wybranych obiektów, opisane już przez innych badaczy. Konieczne było również przeanalizowanie dostępnej literatury i przeanalizowanie źródeł internetowych, bogatych w liczne materiały ikonograficzne - zwłaszcza historyczne. 


\subsection{Jaśkowa Dolina}

Ta część Wrzeszcza to zielona oaza w mieście - to dolina wciśnięta pomiędzy pasmami „zielonych" wzgórz. Ponad 200 lat temu Johan Labes, zamożny przedsiębiorca i senator Wolnego Miasta Gdańska nabył te tereny i zagospodarował - na łąkach i nieużytkach kazał sadzić drzewa, zbudował altany i mostki, a stworzony w ten sposób prywatny park, który docelowo udostępnił mieszkańcom Gdańska! Jaśkowa Dolina stała się modna i zaczęła przyciągać gdańskich milionerów, którzy w tej zielonej i cichej enklawie zaczęli budować swoje podmiejskie wille i pałacyki. Późniejszy burzliwy rozwój całej dzielnicy Wrzeszcz radykalnie zwiększył ruch na trakcie - ulicy wiodącej środkiem doliny.

Dziś Jaśkowa Dolina - wywodząca swoją nazwę od rodziny Kohne-Jaski władającej w XVI w. tymi terenami - jest jednym z najpiękniejszych, zachowanych w Gdańsku, miejsc. Wzgórza i części parku noszą imiona gdańskich osobistości - Jana Heweliusza (niem. Johann Hewelcke) i Johannesa Gutenberga. Dziś dawny park jest od 1958 roku lasem komunalnym, w którym wieczorne spacery nie są już bezpieczne.

\subsection{Wille przełomu $X I X / X X$ wieku}

Na przełomie XIX i XX wieku Jaśkowa Dolina (Wrzeszcz Górny) przyciągała coraz więcej możnych gdańszczan, kupców i fabrykantów - nawet z Łodzi i Bydgoszczy, którzy budowali tu swoje wille podmiejskie, wykorzystujące okoliczne łąki i dogodne widokowo stoki okolicznych wzgórz. Ta część Wrzeszcza, z uwagi na atrakcyjne warunki krajobrazowe, stawała się coraz bardziej modna - na parcelach wzdłuż tej drogi powstawały eklektyczne wille $z$ ogrodami. Podobne eklektyczne formy i detale otrzymywały wielorodzinne kamienice wznoszone przy głównej ulicy (Jäschkenthaler Weg) przebiegającej dnem doliny. Po II wojnie światowej opuszczone przez Niemców wille i kamienice zasiedlili nowi lokatorzy, którzy przez wiele jeszcze lat nie identyfikowali się z tym dziedzictwem - zwykle nie dbając dostatecznie o ich właściwe utrzymanie.

\subsection{Ważniejsze zachowane obiekty}

Dziś część zachowanych budynków ponownie zmieniło właścicieli i przeszła prace remontowe i rewitalizacyjne, część - niestety - nadal nie ma dbałego właściciela i popada szybko w ruinę.

Jaśkowa Dolina 45. Przy wejściu do dawnego parku Johana Labesa znajduje się wybudowana w 1884 roku w stylu szwajcarsko-tyrolskim drewniana willa - dawna leśniczówka (niem. Forsthaus), później restauracja, a obecnie „tylko” budynek mieszkalny.

Jaśkowa Dolina 44 - Willa Kirsch. Zbudowana w 1856 roku a od 1995 znajduje się w rejestrze zabytków. W latach 1994-2007 była tu siedziba Konsulatu Generalnego Ukrainy. Dziś willa jest własnością prywatną po generalnym remoncie. Zaprojektowany na nowo ogród otrzymał kilka międzynarodowych nagród - m.in. w A'design Award \& Competition i w Design Award 2015 Los Angeles.

Jaśkowa Dolina 31 - Willa Freymann. Wybudowana przez, zajmującego się handlem rękodziełem i artykułami mody, kupca Caspara Freymanna w 1902 r. W 1920 roku willa była własnością Banku Bałtyckiego, od 1924 r. właścicielem jest fabrykant (późniejszy konsul Republiki Haiti - Luis Luchtenstein, a następnie od 1942 r. handlarz drewnem - Helmut Koschnik. Obecnie willa jest siedzibą Polskiej Akademii Nauk.

Jaśkowa Dolina 19 - Willa Schrey. Zbudowana w 1899 r. była własnością dyrektora fabryki wagonów - Otta Schreya, Jej surowy wygląd czyni ją nieco tajemniczą

Pawłowskiego 2A - Willa Gollner (Henkenhaf). Powstała w 1902 r. - bajkowa architektura tego domu od razu przyciąga wzrok przechodnia, a jej wygląd właściwie nie zmienił się do dziś. Nawet stolarka okienna wymieniona na współczesną - dwuszybową - utrzymała pierwotny ich „rysunek” tj. podział formalny. 
Pawłowskiego 3 - eklektyczna willa zbudowana w 1899 r. ma szachulcową konstrukcję poddasza oraz oszczędny, formowany w tynku detal. Całość po pracach remontowych jest dziś w dobrym stanie technicznym.

Pawłowskiego 1A. To kolejna eklektyczna willa z przełomu XIX i XX wieku. Posiada mieszkania na wynajem/sprzedaż o $4 \%$ droższe niż w centrum dzielnicy. Dach jest po remoncie, lecz wcześniejsza niedrożność orynnowania uszkodziła tynki zewnętrzne elewacji frontowej. Willa, podobnie jak budynek sąsiedni ma wymienioną stolarkę okienną na nowoczesną - dwuszybową. Drzwi frontowe są oryginalne - płycinowe $z$ naświetlem.

Willa operuje typowymi dla okresu w jakim powstała elementami konstrukcyjnymi i zdobniczymi z podkreśleniem w szczytach ścian rysunku ich szachulcowej konstrukcji.

Ulica Sobótki 14 - dawny budynek Café Zinglershöhe i Villa Litewski. Ulica ta, łącząca dużym łukiem ulice Jaśkowa Dolina i Matejki, prowadzi m.in. do pozostałości dawnej kawiarni Zinglera i sąsiadującej z nimi willi doktora Michała Litewskiego.

W 1843 roku na wzniesieniu zwanym Górą Jana (Joannisberg) gdański kupiec Zingler zbudował gospodę w stylu szwajcarskim (Gasthaus) - nazwaną pierwotnie Bellevue (Piękny Widok). Jednak w powszechnym użycie była potoczna nazwa dla restauracji i wzgórza - Zinglerhohe (Wzgórze Zinglera). 25 lat później restauracja zyskała przeszklony taras - werandę. Restauracja kilkakrotnie zmieniała właścicieli, ulegając także kolejnym przebudowom, a w latach 1925-1933 budynek należał do Loży Masońskiej. Pod koniec 1941 roku lokal został zamknięty.

Po II wojnie światowej funkcjonował tu jeszcze lokal (Cyganeria) z dancingiem, a po remoncie w 1950 egzystował tu dom kultury - kinem i kawiarnią. W 1959 roku restauracja wraz z sąsiednią Willą Litewski stały się siedzibą telewizji Gdańsk. Po wyprowadzce TVP w 1996 r. do nowej siedziby, oba budynki w szybkim tempie niszczeją.

W ubiegłym roku nowy właściciel - deweloper deklaruje wybudowanie na wzgórzu kilku apartamentowców „dopasowanych” do charakteru otoczenia i tradycji Jaśkowej Doliny... Istniejące objęte ochroną prawną (willa i część dawnej restauracji) zostaną (podobno) poddane gruntownej renowacji - niestety przez lata zaniedbań wiele elementów konstrukcji, detalu, wykończenia i wyposażenia (głównie w willi) uległo bezpowrotnemu zniszczeniu.

Ulica Pawłowskiego 5 - kamienica z przełomu XIX i XX wieku. Obecnie jest użytkowana przez wspólnotę mieszkaniową i zamieszkała przez kilka rodzin. Budynek ma zwartą bryłę, wymienione pokrycie oraz stolarkę okienną. Jest dobrze widoczny z ulicy i dostępny. Niestety pęknięcia ścian zewnętrznych mogą świadczyć o jego słabych fundamentach bądź o zaburzonych warunkach gruntowo-wodnych. Drzwi wewnętrzne i zewnętrzne, schody i posadzki są jeszcze oryginalne. Na elewacji sztukaterie w tynku o motywach roślinnych. Frontowe naroże zdobi rzeźba Diany.

Ul. Batorego 8 - kamienica czynszowa. Jest to budynek 3 kondygnacyjny w którym dwie kondygnacje poddasza mają konstrukcję szkieletową - szachulcową. Jest to budynek wielorodzinny w którym struktura drewnianego szkieletu pełni ważną rolę zdobniczą - podkreśloną kolorem jego elementów. Niewidoczna z ulicy elewacja pokazuje znaczne zaniedbanie konserwatorskie - ubytki pokrycia dachówkowego i systemu odwadniającego.

\section{PODSUMOWANIE I WNIOSKI}

Architektura willowa i kamienice Górnego Wrzeszcza z przełomu XIX i XX wieku jest dziś świadectwem zasobności finansowej i aspiracji mieszczan, inteligencji, kupców i przedsiębiorców Wolnego Miasta Gdańsk. Udział w międzynarodowym handlu morskim i związki z państwem pruskim był podstawą rozwoju miasta i regionu. $\mathrm{W}$ architekturze owocowało to budową obiektów przemysłowych, rozwojem infrastruktury komunikacyjnej, budową obiektów użyteczności publicznej a także budową większych i mniejszych budynków mieszkalnych.

Zdecydowana większość realizacji tamtego okresu to formy i detale eklektyczne, dopiero początek XX wieku przynosi formy uproszczone i poddane innej logice i innym założeniom projektowym. 
Rzec można, że przeważała jednak siła tradycji i klasycznego kształcenia architektów na uczelniach niemieckich i w Wiedniu. Kompilacje różnych motywów historycznych przetaczały się przez Europę i resztę świata udowadniając siłę tradycji i przyzwyczajenia, a także rangę dotychczasowych kanonów estetycznych.

W rezultacie ówczesny świat form „cywilizowanych” (przez projektantów) form jawił się jako nieomal bajkowy, w którym forma i zdobiący ją detal były jakby przedłużeniem świata dziecięcych marzeń. Dziś okazuje się, że po ponad 120 latach formy te nadal są atrakcyjne - podobnie jak bliskie są nam „kolory i smaki” dzieciństwa. Nie dziwi więc, że fascynacji tamtą architekturą ulegają kolejne pokolenia użytkowników i odbiorców. Działania wojenne oszczędziły większość zabudowy podmiejskiej Gdańska, Oliwy i Sopotu. Niestety totalna zmiana właścicielska części z niej nie sprzyjała. Dziś wiele budynków - tak willowych jak i wielorodzinnych kamienic - ujawnia niestety znaczny stopień technicznej destrukcji. „Najlepszym” tego przykładem jest zespół obiektów opuszczonych przez Telewizję Gdańsk na Górze Jana, przy ul. Sobótki 14. Niestety w skali kraju podobnych przykładów negatywnych jest aż nadto.

Minęło 75 lat od wojennej hekatomby - odbudowana została gdańska Starówka, a tereny podmiejskie powoli odzyskują dawny blask. Uroda Jaśkowej doliny - jej atrakcyjność krajobrazowa i architektoniczne perełki - zasługują dziś na szczególną ochronę by nie traciły swoich dotychczasowych walorów. Zagrożeniem jest tu - niestety - drapieżna, nie licząca się z tradycją i dorobkiem pokoleń, deweloperka. Dlatego Jaśkowa Dolina - wraz z przyległymi terenami zielonymi i inne podobne strefy Trójmiasta - winny podlegać szczególne ochronie konserwatorskiej.

\section{BIBLIOGRAPHY}

Bogusz T. 2020. Jak Sowieci „wyzwalali” Gdańsk w marcu 1945 roku? https://twojahistoria.pl/2020/04/04/jaksowieci-wyzwalali-gdansk-w-marcu-1945-roku/. Access 2020-07-14

Budnik E. 2019. https://dom.trojmiasto.pl/Nowe-zycie-bylego-terenu-telewizji-przy-Sobotki-n135428.html. Access 2020-05-12

Budnik E., Nowe życie byłego terenu telewizji przy Sobótki, 16 czerwca 2019, w: https://dom.trojmiasto.pl/Nowe-zycie-bylego-terenu-telewizji-przy-Sobotki-n135428.html

Budynek TVP Gdańsk, ulica Sobótki, 25/07/2013 w: http://nandi.pl/index.php?go=zdj_ruiny34

Daniluk J., Wasielewski J. 2017. https://historia.trojmiasto.pl/Wrzeszczanska-restauracja-z-widokiem-naZatoke-Gdanska-Historia-Cafe-Zinglershohe-n110483.html. Access 2020-05-12

Daniluk J., Wasilewski J., Dawna restauracja z widokiem na Zatokę Gdańską. Historia Café Zinglershöhe w: https://historia.trojmiasto.pl/Wrzeszczanska-restauracja-z-widokiem-na-Zatoke-Gdanska-Historia-CafeZinglershohe-n110483.html

Frąckowska A., Gdańskie zakłady litograficzne w XIX i XX wieku Lithographic establishments in Gdansk in the 19th and 20th centuries w: Drukowane piękno, PAN Biblioteka Gdańska, ASP w Gdańsku - Wydział Grafiki, t.1, Gdańsk 2019

Gdańsk-Wrzeszcz. Artinfo.pl. https://artinfo.pl/dzielo/gdansk-wrzeszcz-0561be15-97ba-422d-89f36a5ade08b347 Access 2020-07-14

Jaśkowa Dolina https://www.gedanopedia.pl/gdansk/?title=JAŚKOWA_DOLINA. Access 2020-07-15

Jeschkenthal litografia. Access 2020-07-17 
Kowalska E. 2011. Gdańsk Wrzeszcz: Zrujnowana Willa Loży Masońskiej https://ibedeker.pl/obiekty/wlasnosctelewizji-gdansk-czyli-zrujnowana-zabytkowa-willa/\#axzz1JoF7vjb1. Access 2020-07-14

Kowalska E., Zrujnowana willa Loży Masońskiej, 08/04/2011, w: http://ibedeker.pl/obiekty/wlasnosc-telewizjigdansk-czyli-zrujnowana-zabytkowa-willa/

Krótka historia Wrzeszcza - http://www.danzig-online.pl/historia/hw.html, dostęp/access 15/011/2020

mapa Gdańska z 1912 r http://maps.mapywig.org/m/City_plans/Central_Europe/AMPG_Plan_der_Stadt_Danzig_1912.jpg Access 2020-07-11

Masłowski A., O nie-masońskiej kamienicy przy ul. Sobótki, iBedeker 18/04/2011 w: http://ibedeker.pl/obiekty/o-nie-masonskiej-kamienicy-przy-ulicy-sobotki/

Muzeum. https://muzeumpomorza.pl/resource/3019_gdansk-_wrzeszcz_-jaskowa-dolina.html9. Access 202004-15

Plan der Vorstadt Langfuhr bei Danzig wikimedia.org/wiki/File:Plan_der_Vorstadt_Langfuhr_bei_Danzig.JPG. Access 2020-08-19

Podróże dalekie i bliskie - Gdańsk Wrzeszcz Górny cz. 3. 2016. https://www.gamedesire.com/pl/player/traveler22/blog/2574109. Access 2020-07-15

Przewodnik po Gdańsku, w: htt://pwww.gdansk-przewodnik.euwrzeszcz

Spacerownik Gdański, Jaśkowa Dolina, 3 marca 2019 w: https://okruchykultury.pl/2019/03/03/spacerownikgdanski-2-jaskowa-dolina/\#.X68ZMxbPyUk

Traveler22 - Blog, Podróże dalekie i bliskie - Gdańsk-Wrzeszcz Górny cz.3, 24/12/2014, (plan Wrzeszcza z 1899 r.) w: https://www.gamedesire.com/pl/player/traveler22/blog/2574109

Zimoch M., Jaśkowa Dolina. Dzielnica dawnych milionerów w: https://www.trojmiasto.pl/wiadomosci/JaskowaDolina-Strefa-gdanskich-milionerow-n135219.html

\section{AUTHOR'S NOTE}

Autor zajmuje się historyczną i współczesną architekturą drewnianą oraz murowaną. Publikuje także analizy i opinie nt. jakości form w architekturze współczesnej. Był redaktorem naczelnym ogólnopolskiego kwartalnika ARCHIVOLTA oraz współredaktorem miesięcznika Nasza Politechnika w Krakowie. Przewodniczący sekcji Architektury Drewnianej oddziału Polskiej Akademii Nauk w Krakowie.

\section{O AUTORZE}

The author is interested in historical and contemporary wooden and brick architecture. It also publishes analyzes and opinions on the quality of forms in contemporary architecture. He was the editor-in-chief of the nationwide ARCHIVOLTA quarterly and co-editor of the Nasza Politechnika monthly in Krakow. Chairman of the Wooden Architecture section of the Polish Academy of Sciences in Krakow.

Contact | Kontakt: pakurek@cyf-kr.edu.pl 